\title{
Brain tissue acid-base changes during ischemia
}

\section{William E. Hoffman, Ph.D., Fady T. Charbel, M.D., Guy Edelman, M.D., and James I. Ausman, M.D., Ph.D.}

\section{Departments of Anesthesiology and Neurosurgery, University of Illinois at Chicago, Chicago, Illinois}

It is likely that brain tissue acidosis during ischemia is associated with neuronal injury. The authors measured brain extracellular $\mathrm{H}^{+}, \mathrm{PCO}_{2}$ and $\mathrm{HCO}_{3}$ - concentrations during an ischemic event produced by temporary occlusion of the middle or anterior cerebral arterial distributions, with a 10-minute recovery period. Patients who were to undergo craniotomy for cerebrovascular surgery were recruited for the study. A probe that measures $\mathrm{PCO}_{2}, \mathrm{pH}$, and temperature was inserted into tissue at risk for ischemia during temporary arterial occlusion. As a control for this treatment, $\mathrm{PaCO}_{2}$ was increased $10 \mathrm{~mm} \mathrm{Hg}$ in five patients over a 10-minute period. Under baseline conditions, there was no difference in arterial blood pressure, blood gas levels, or brain temperature between patients who underwent temporary arterial occlusion or those in whom hypercapnia was induced. In patients in whom hypercapnia was induced, $\mathrm{H}^{+}$, $\mathrm{PCO}_{2}$, and $\mathrm{HCO}_{3}{ }^{-}$concentrations increased and all values returned to baseline levels within 10 minutes. In 10 patients who underwent a median 9-minute arterial occlusion, transient ischemia was seen with an increase in tissue $\mathrm{H}^{+}$and $\mathrm{PCO}_{2}$ levels of $100 \%$ and $60 \%$, respectively, and a $20 \%$ decrease in $\mathrm{HCO}_{3}{ }^{-}$ levels. After a 10-minute postischemic recovery, only $\mathrm{PCO}_{2}$ had returned to baseline levels. These results are consistent with a rapid equilibration of lactic acidosis across the cell membrane during ischemia which decreases $\mathrm{HCO}_{3}{ }^{-}$concentration. After ischemia, extracellular acidosis may be prolonged because of the extrusion of $\mathrm{H}^{+}$from the cell by membrane ion exchange.

Key Words * ischemia * hydrogen ion * carbon dioxide * bicarbonate * aneurysm clipping

During cerebral ischemia, brain tissue $\mathrm{H}^{+}$concentration is stable until tissue blood flow falls to 35 $\mathrm{ml} \cdot 100 \mathrm{~g}^{-1} \cdot \mathrm{min}^{-1}$, below which it increases markedly.[6,14] Anaerobic metabolism initiated by ischemia induces lactic acidosis and elevated tissue $\mathrm{PCO}_{2} \cdot[9,10,19]$ However, it is unclear whether the extracellular $\mathrm{HCO}_{3}{ }^{-}$concentration is decreased.[20,22] After an ischemic episode, extended tissue acidosis may contribute to neuronal injury, but the changes in tissue acid base during this period are not clear.[18,20] It is also not understood how ischemic changes in tissue acid base reported in animal models relate to temporary ischemia in humans. We have measured brain tissue acid base changes during an ischemic insult produced by occlusion of a middle or anterior cerebral distribution artery in patients undergoing craniotomy for cerebrovascular surgery. These changes were compared with a control group 
of patients in whom respiratory acidosis was induced by artificially decreasing ventilation.

\section{CLINICAL MATERIAL AND METHODS}

\section{Patient Population}

Eighteen patients undergoing craniotomy for cerebrovascular surgery were evaluated. Tissue gas levels and $\mathrm{H}^{+}$concentrations were measured during arterial occlusion to facilitate aneurysm clipping in 12 patients or arteriovenous malformation resection in one patient. In five other patients, $\mathrm{PaCO}_{2}$ was increased by $10 \mathrm{~mm} \mathrm{Hg}$ as a control treatment for cerebral arterial occlusion. These studies were approved by the institutional review board for clinical research and informed consent was received.

\section{Surgical Procedure}

Patients were anesthetized with 10 to $15 \mu \mathrm{g} / \mathrm{kg}$ fentanyl and 3 to $5 \mathrm{mg} / \mathrm{kg}$ thiopental; they were paralyzed with $100 \mu \mathrm{g} / \mathrm{kg}$ vecuronium, intubated, and ventilated with $0.8 \%$ end-tidal isoflurane. The fraction of inspired $\mathrm{O}_{2}$ was 0.4 and $\mathrm{PaCO}_{2}$ was maintained between 30 and $35 \mathrm{~mm} \mathrm{Hg}$. Esophageal temperature was allowed to decrease to $35 \mathrm{~s} \mathrm{C}$. A radial artery catheter was inserted to measure arterial pressure and to obtain arterial blood gas samples. Electroencephalographic (EEG) recordings were made using electrodes placed on the skin over the forehead. (model A1000 EEG monitor; Aspect, Boston, MA). A craniotomy was performed and the dura was retracted.

\section{Intraoperative Monitoring}

A probe (Paratrend 7 sensor; Biomedical Sensors, High Wycombe, UK) was inserted $4 \mathrm{~cm}$ into the cortex in all patients. The sensor probe was inserted into tissue within the arterial distribution at risk for ischemia during cerebral arterial occlusion. The sensor is supplied as a sterile, disposable device composed of two modified optical fibers for the measurement of $\mathrm{PCO}_{2}$ and $\mathrm{H}^{+}$, and a thermocouple for the determination of temperature. The outer surface of the sensor has a covalently bonded heparin coating. The $\mathrm{pH}$ and $\mathrm{PCO}_{2}$ sensors are separated by $1 \mathrm{~cm}$ at the end of the probe, which is $0.5 \mathrm{~mm}$ in diameter. The void between the sensors is filled with acrylamide gel containing phenol red. Changes in $\mathrm{H}^{+}$concentration produce color changes in phenol red, which can be detected by the $\mathrm{H}^{+}$fiberoptic element. The $\mathrm{CO}_{2}$ sensor includes an ion impermeable barrier that excludes the movement of $\mathrm{H}^{+}$but allows the movement of $\mathrm{CO}_{2}$. Inside the barrier, $\mathrm{CO}_{2}$ alters the local $\mathrm{H}^{+}$, producing a color change in phenol red that is detected by the $\mathrm{CO}_{2}$ fiberoptic elements. The $\mathrm{PCO}_{2}$ and $\mathrm{H}^{+}$measurements were corrected for local temperature to $37 \check{\mathrm{s}} \mathrm{C}$. Tissue $\mathrm{HCO}_{3}{ }^{-}$was calculated from $\mathrm{PCO}_{2}$ and $\mathrm{pH}$ measurements using the Henderson-Hasselbalch equation.[3]

The sensor is packaged with a tonometer containing buffer solution that serves as a calibrating medium. Before the sensor was inserted into the patient it was calibrated with precision gases supplied with the monitor. The $\mathrm{CO}_{2}$ and $\mathrm{pH}$ calibration curves are constructed within the range of 10 to $80 \mathrm{~mm} \mathrm{Hg}$ and 6.80 to 7.80 , respectively, using the three $\mathrm{CO}_{2}$ gas concentrations: $2 \%, 14 \mathrm{~mm} \mathrm{Hg}(\mathrm{pH}=7.83) ; 5 \%, 36$ $\mathrm{mm} \mathrm{Hg}(\mathrm{pH}=7.43)$; and $10 \%, 71 \mathrm{~mm} \mathrm{Hg}(\mathrm{pH}=7.13)$. The range and 95\% confidence interval limits for each sensor were determined in in vitro testing: $\mathrm{CO}_{2}$ range, 10 to $80 \mathrm{~mm} \mathrm{Hg}, 95 \%$ confidence limits \pm 3 $\mathrm{mm} \mathrm{Hg}$; and $\mathrm{pH}$ range, 6.80 to $7.80,95 \%$ confidence limits \pm 0.03 . The 0 to $90 \%$ response time for each sensor was: $\mathrm{CO}_{2}, 143$ seconds and $\mathrm{pH}, 78$ seconds. 
After a 30-minute equilibration period, baseline measures of end-tidal $\mathrm{CO}_{2}$ and anesthetic gas levels (Datex Instruments, Helsinki, Finland), mean arterial pressure (MAP), blood and brain tissue $\mathrm{PCO}_{2}, \mathrm{H}^{+}$, and temperature were recorded. Arterial blood pressure, end-tidal gas levels, and tissue data were collected by computer using Labview (National Instruments, Dallas, TX) every 10 seconds.

\section{Protocol Response}

In patients undergoing occlusion, etomidate $(0.2-0.4 \mathrm{mg} / \mathrm{kg})$ was given to induce a burst suppression EEG response before the temporary clip was placed. After 3 to 5 minutes of burst suppression EEG activity, a temporary clip was placed on the middle cerebral artery (MCA) in 10 patients or the anterior cerebral artery (ACA) in three. The changes in tissue gas levels, $\mathrm{H}^{+}$, and $\mathrm{HCO}_{3}{ }^{-}$were measured during arterial occlusion and for a 10 -minute recovery period.

In five patients, steady-state baseline values were obtained for arterial blood gas levels, MAP, and tissue $\mathrm{PO}_{2}, \mathrm{PCO}_{2}$ and $\mathrm{H}^{+}$, and then the ventilation rate was decreased to increase $\mathrm{PaCO}_{2} 10 \mathrm{~mm} \mathrm{Hg}$ over a 10-minute period. The $\mathrm{PaCO}_{2}$ was then returned to baseline levels. In both treatment groups, end-tidal isoflurane was constantly maintained during the experiment.

\section{Statistical Analysis}

Data are reported as the mean \pm standard deviation. Baseline MAP, arterial blood and tissue $\mathrm{PCO}_{2}, \mathrm{H}^{+}$, and $\mathrm{HCO}_{3}{ }^{-}$were compared between the groups using t-tests. Changes in tissue $\mathrm{PCO}_{2}, \mathrm{H}^{+}$, and $\mathrm{HCO}_{3}{ }^{-}$ during arterial occlusion were compared to baseline measurements within each group using repeated-measures analysis of variance and paired t-tests used for post hoc comparisons. A Pearson Product Moment correlation was calculated using the change in $\mathrm{H}^{+}$produced by ischemia and the $\mathrm{H}^{+}$ concentration at the end of the recovery period.

\begin{tabular}{|c|c|c|c|c|c|c|}
\hline \multicolumn{7}{|c|}{$\begin{array}{c}\text { TABLE } 1 \\
\text { BASELINE MAP, } \mathrm{PAO}_{2}, \mathrm{PACO}_{2}, \text { PH, AND BRAN TEMPERATURE } \\
\text { LEVELS IN PATIENTS IN WHOM AN INCREASE IN ARTER IAL CO }{ }_{2} \text { OR } \\
\text { ISCHEMA WAS PRODUCED }{ }^{\star}\end{array}$} \\
\hline Group & $\begin{array}{l}\text { No. of } \\
\text { Patients }\end{array}$ & $\begin{array}{c}\mathrm{MAP} \\
\mathrm{s}(\mathrm{mm} \mathrm{Hg})\end{array}$ & $\underset{\left[\mathrm{PaO}_{2}\right.}{\mathrm{Pam}_{\mathrm{g}}}$ & $\begin{array}{c}\mathrm{PaCO}_{2} \\
\left(\mathrm{~mm} \mathrm{H}_{\mathrm{g}}\right)\end{array}$ & apH & $\begin{array}{c}\text { Brain } \\
\text { Temp }\left({ }^{\circ} \mathrm{C}\right)\end{array}$ \\
\hline $\begin{array}{l}\text { percapnia } \\
\text { themia }\end{array}$ & $\begin{array}{c}5 \\
10 \\
\end{array}$ & $\begin{array}{l}82 \pm 15 \\
81 \pm 11\end{array}$ & $\begin{array}{l}176 \pm 41 \\
185 \pm 60\end{array}$ & $\begin{array}{l}32 \pm 4 \\
33 \pm 4\end{array}$ & $\begin{array}{r}7.4 \pm 0.05 \\
7.41 \pm 0.04\end{array}$ & $\begin{array}{c}36 \pm 0.8 \\
35.4 \pm 1.6\end{array}$ \\
\hline
\end{tabular}

\section{RESULTS}

Under baseline conditions there was no significant difference in arterial blood pressure, blood gas levels, and $\mathrm{pH}$ and brain temperature between patients who received a $\mathrm{CO}_{2}$ challenge and those in whom a cerebral artery was occluded (Table 1). Three patients in whom an artery was clipped were not included in the analysis. Two of these patients did not show ischemic changes during temporary ACA occlusion. In a third patient, an arterial clip that was placed to stop bleeding during AVM resection was not removed. Tissue $\mathrm{pH}$ decreased from 7.19 to 6.36 and tissue $\mathrm{PCO}_{2}$ increased from $45 \mathrm{~mm} \mathrm{Hg}$ to $145 \mathrm{~mm}$ $\mathrm{Hg}$ after the clip was placed. This patient developed seizures in the postoperative period and died on 
postoperative Day 2. Other patients in whom a temporary artery clip was placed showed ischemic changes in tissue $\mathrm{pH}$ and $\mathrm{PCO}_{2}$ and recovery when the clip was removed. An example of the changes in tissue $\mathrm{PCO}_{2}, \mathrm{H}^{+}$, and $\mathrm{HCO}_{3}{ }^{-}$during arterial occlusion is shown in Fig. 1.

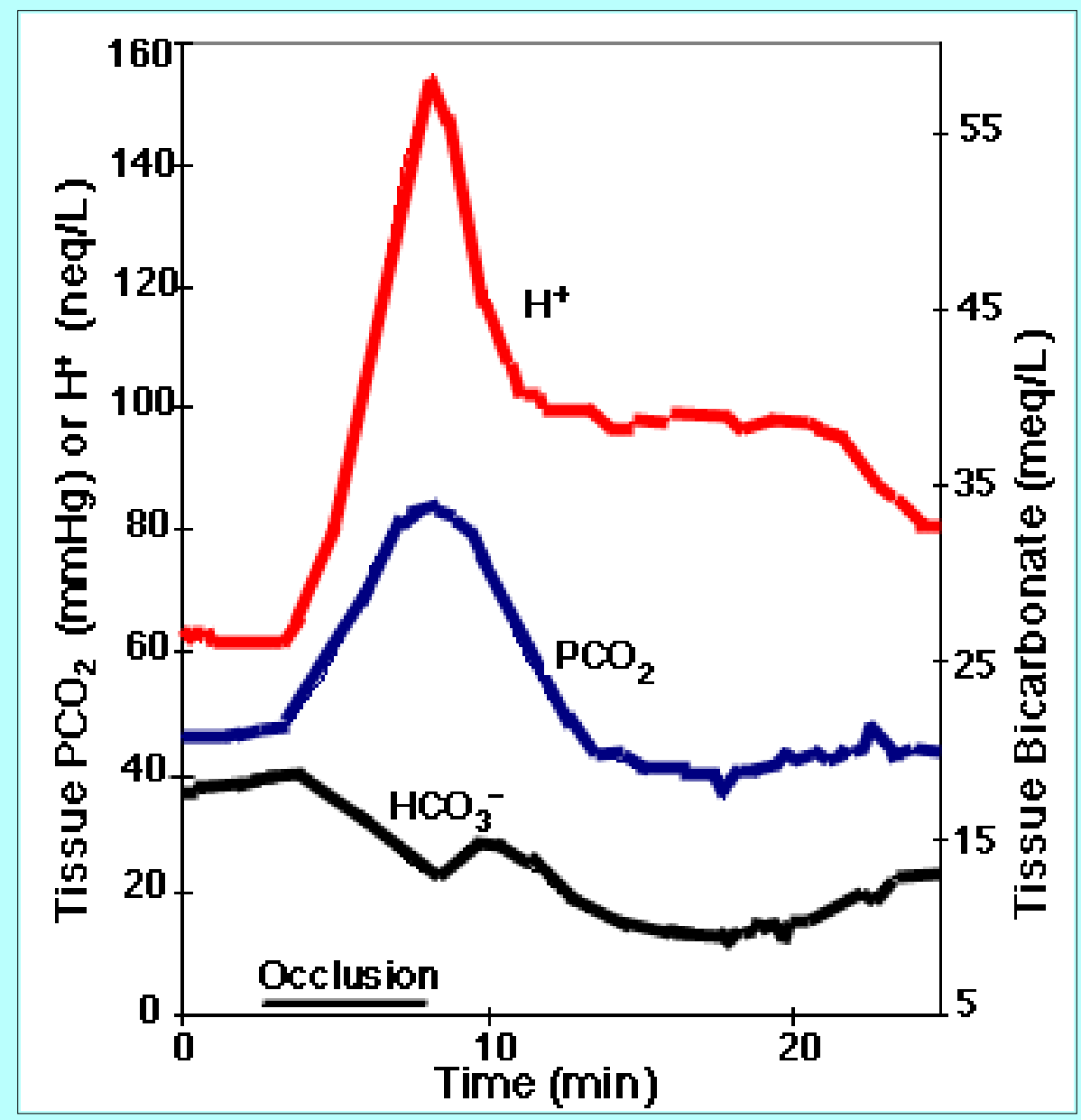

Fig. 1. Graph showing tissue $\mathrm{H}^{+}, \mathrm{PCO}_{2}$, and $\mathrm{HCO}_{3}{ }^{-}$levels in a representative patient during MCA occlusion. Arterial clipping resulted in an increase in $\mathrm{PCO}_{2}$ and $\mathrm{H}^{+}$and a decrease in $\mathrm{HCO}_{3}{ }^{-}$. After clip removal, $\mathrm{PCO}_{2}$ returned to baseline levels, but there was a secondary decrease in $\mathrm{HCO}_{3}{ }^{-}$concentration. This was associated with a prolonged decrease in $\mathrm{H}^{+}$ concentration in the extracellular space.

Tissue $\mathrm{PCO}_{2}$ and $\mathrm{H}^{+}$increased simultaneously while $\mathrm{HCO}_{3}$ - decreased during the period of occlusion. The $\mathrm{PCO}_{2}$ decreased to baseline levels within 5 minutes after the occlusion; however, $\mathrm{H}^{+}$remained elevated. After blood flow was reestablished, tissue $\mathrm{HCO}_{3}{ }^{-}$decreased below ischemic levels. A similar ischemic response was seen in the 10 patients who underwent occlusion for aneurysm clipping (Fig. 2). 

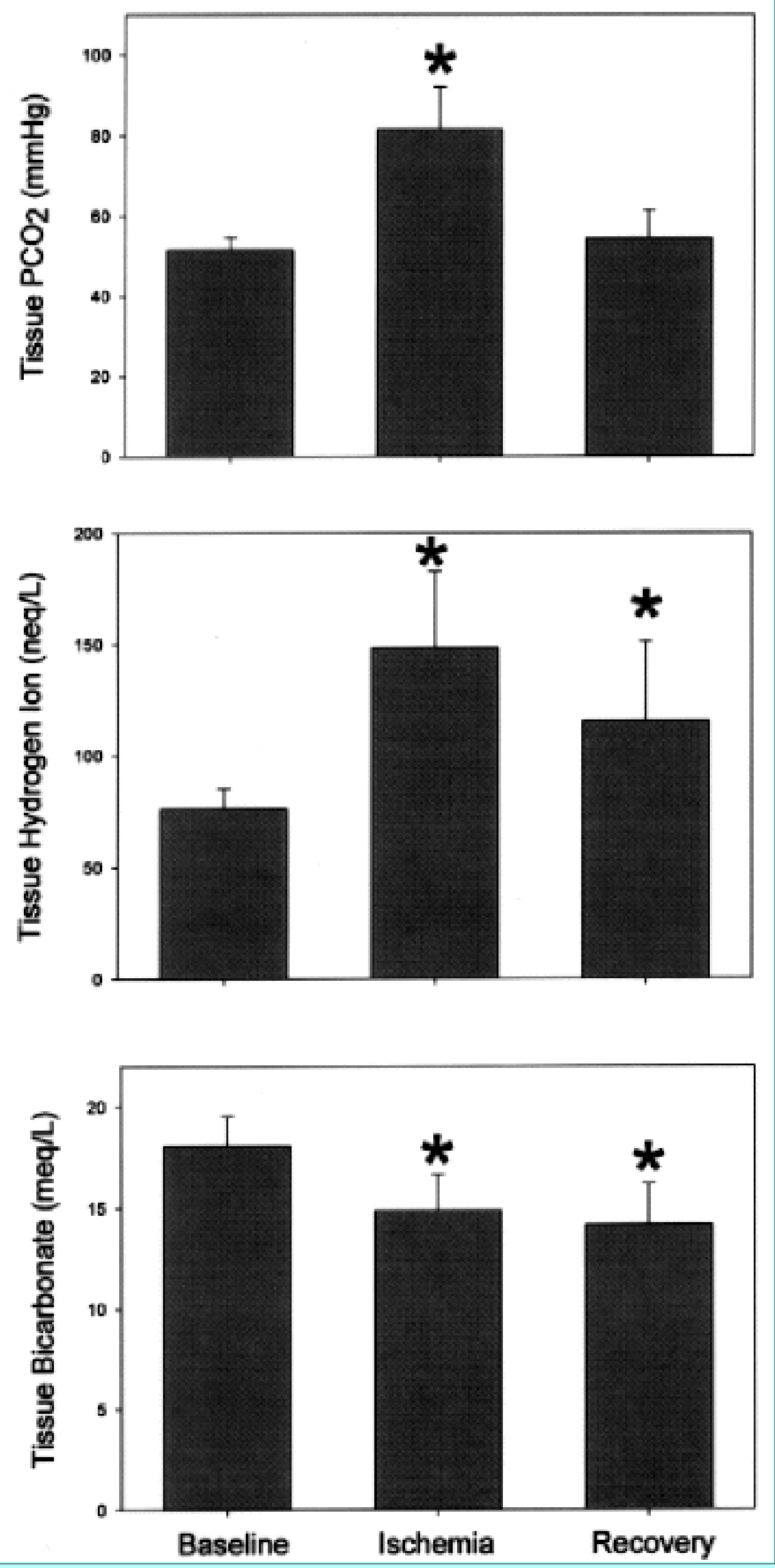
Fig. 2. Bar graphs showing tissue $\mathrm{PCO}_{2}, \mathrm{H}^{+}$, and $\mathrm{HCO}_{3}{ }^{-}$levels during ischemia and 10 minutes after recovery from ischemia in nine patients. Ischemia was associated with an increase in $\mathrm{PCO}_{2}$ and $\mathrm{H}^{+}$concentration and a decrease in $\mathrm{HCO}_{3}{ }^{-}$. Ten minutes after ischemia ceased, $\mathrm{PCO}_{2}$ was not different from baseline, but $\mathrm{H}^{+}$was still increased and $\mathrm{HCO}_{3}{ }^{-}$was decreased compared with baseline levels.

The median time of temporary clipping was 9 minutes (range 2-35 minutes). Tissue $\mathrm{H}^{+}$and $\mathrm{HCO}_{3}{ }^{-}$did not return to baseline levels within the 10-minute recovery period after ischemia, and there was a significant correlation between the decrease in $\mathrm{pH}$ during ischemia and the $\mathrm{pH}$ in the recovery period $(\mathrm{r}=$ 0.96, $\mathrm{p}<0.001$ ). During the $\mathrm{CO}_{2}$ challenge, $\mathrm{PaCO}_{2}$ increased $10 \pm 1 \mathrm{~mm} \mathrm{Hg}$ in the five patients tested. Tissue $\mathrm{PCO}_{2}, \mathrm{H}^{+}$, and $\mathrm{HCO}_{3}$ - increased and then returned to baseline levels within 10 minutes of recovery (Fig. 3).

Fig. 3. Bar graphs showing tissue $\mathrm{PCO}_{2}$, $\mathrm{H}^{+}$, and $\mathrm{HCO}_{3}^{-}$levels during hypercapnia produced by a decrease in ventilation in five patients. Concentrations of $\mathrm{PCO}_{2}, \mathrm{H}^{+}$, and $\mathrm{HCO}_{3}^{-}$ increased during hypercapnia and returned to baseline levels 10 minutes after ventilation was returned to normal.

\section{DISCUSSION}

In this study we found that during hypercapnia there is a small but significant rise in brain tissue $\mathrm{HCO}_{3}{ }^{-}$concentration. This is consistent with previous studies that suggest that $\mathrm{H}^{+}$ movement from the extracellular space or $\mathrm{HCO}_{3}{ }^{-}$movement in the opposite direction may occur during increases in tissue $\mathrm{PCO}_{2} \cdot[8,11]$ This may involve energy-requiring ion transport across the cell membrane because the increase in extracellular $\mathrm{HCO}_{3}{ }^{-}$is abolished by acidosis or hypoxia. In contrast to the $\mathrm{CO}_{2}$ challenge, we found ischemia produced by temporary arterial occlusion resulted in an increase in $\mathrm{H}^{+}$and $\mathrm{PCO}_{2}$ and a reduction of tissue $\mathrm{HCO}_{3}{ }^{-}$. In the recovery period, tissue $\mathrm{PCO}_{2}$ returned to baseline levels; however, $\mathrm{H}^{+}$remained elevated and $\mathrm{HCO}_{3}{ }^{-}$was further reduced. This may be 
caused by $\mathrm{H}^{+}$extrusion from the intracellular to the extracellular space as the neurons recover from the ischemic event.

\section{Ischemic Acidosis}

Kraig, et al.,[12] showed that excessive acidosis can kill neurons; they injected lactic acid into brain tissue and observed an infarction when extracellular $\mathrm{pH}$ was less than 5.30. In vitro studies have shown that extracellular acidosis produced by lactate produces neuronal death more rapidly than $\mathrm{HCl}$.[4] This is likely because of the ability of lactate to diffuse easily across the membrane barrier and decrease intracellular $\mathrm{pH}$. Modest extracellular acidosis has produced a delayed cell death seen at 48 hours.[15] This is similar to delayed cell death seen after ischemia and is independent of glutamate activity. These results indicate that the onset time of neuronal death is related to the severity and the length of tissue acidosis.

It is possible that acid-sequestering mechanisms in glial cells protect neurons from $\mathrm{H}^{+}$-induced injury. In a rat model of complete ischemia, Kraig, et al.,[13] found that extracellular $\mathrm{H}^{+}$did not change, whereas lactate concentration increased to 15 to $17 \mathrm{mmol} / \mathrm{kg}$. They suggested that maintenance of a constant extracellular $\mathrm{H}^{+}$concentration even while lactate is increasing is caused by $\mathrm{H}^{+}$accumulation by astroglia. However, this was not supported by Katsura, et al.,[10] who found a linear relationship between tissue $\mathrm{PCO}_{2}, \mathrm{H}^{+}$, and lactate in rats during ischemia. Because the rise they observed in $\mathrm{PCO}_{2}$ and $\mathrm{H}^{+}$was directly related to the rise in tissue lactate, this does not support the presence of an acid-sequestering glial compartment. Our results do not speak directly to this issue because we did not measure lactate changes during the period of ischemia. However, the fact that $\mathrm{PCO}_{2}$ and $\mathrm{H}^{+}$increased with the onset of ischemia in this study (Fig. 1) suggests that acid-sequestering mechanisms were not present.

Neuronal acidosis in the intracellular space may be attenuated during ischemia compared with the extracellular space. Nedergaard, et al.,[16] measured both extracellular and intracellular pH during MCA occlusion with a pH electrode and ${ }^{14} \mathrm{C}$-methadione, respectively. At 1 hour of occlusion they found that extracellular $\mathrm{pH}$ decreased from 7.24 to 6.43 , but that intracellular $\mathrm{pH}$ only decreased from 7.01 to 6.86 . At 4 hours $\mathrm{pH}$ was 6.6 in both compartments. Insulin-induced hypoglycemia attenuated the decrease in extracellular $\mathrm{pH}$, whereas hyperglycemia worsened it. This suggests that neurons can extrude $\mathrm{H}^{+}$into the extracellular space during the initial stages of ischemia, possibly by membrane ion exchange; however, other results do not support this. During 15 minutes of near-complete ischemia, Von Hanwehr, et al.,[22] reported that tissue $\mathrm{PCO}_{2}$ increased from 45 to $149 \mathrm{~mm} \mathrm{Hg}$ and lactate increased from 2 to $15 \mu \mathrm{mol} / \mathrm{g}$. Extracellular $\mathrm{pH}$ decreased from 7.3 to 6.7 and intracellular $\mathrm{pH}$ decreased from 7.0 to 6.2. Intracellular $\mathrm{HCO}_{3}$ - decreased from 10.5 to $5.2 \mu \mathrm{mol} / \mathrm{g}$, but extracellular $\mathrm{HCO}_{3}$ - did not change. They suggested that the greater decrease in intracellular compared to extracellular $\mathrm{pH}$ was due to a lack of equilibrium of lactate and $\mathrm{H}^{+}$movement between the intracellular and extracellular space. In a similar study, Smith, et al.,[20] found that brain tissue lactate increased to $10 \mu \mathrm{mol} / \mathrm{g}$ and $20 \mu \mathrm{mol} / \mathrm{g}$ in hypoglycemic and hyperglycemic rats, respectively, and extracellular $\mathrm{pH}$ decreased to 6.8 and 6.2, respectively, during incomplete ischemia. Tissue $\mathrm{PCO}_{2}$ increased to $146 \mathrm{~mm} \mathrm{Hg}$ (hypoglycemic) and $192 \mathrm{~mm} \mathrm{Hg}$ 
(hyperglycemic) and could be accounted for primarily by the decrease in intracellular $\mathrm{HCO}_{3^{-}}$. Extracellular $\mathrm{HCO}_{3}$ - decreased greather than $10 \mu \mathrm{mol} / \mathrm{g}$ in hyperglycemic but not in hypoglycemic rats during ischemia. They suggested that $\mathrm{HCO}_{3}$ - transport from the intracellular to the extracellular space may explain the lack of change in extracellular $\mathrm{HCO}_{3}$ - in hypoglycemic rats. Our measures indicate that extracellular $\mathrm{HCO}_{3}$ - decreases even during short and modest ischemic events. This is consistent with previous studies that indicate there is a rapid equilibration of lactate across the cell membrane, which decreases intracellular and extracellular $\mathrm{HCO}_{3^{-} \cdot[15]}$

In addition to ischemic acidosis, we observed a postischemic period when extracellular acidosis was prolonged and $\mathrm{HCO}_{3}$ - concentration did not recover, even as $\mathrm{PCO}_{2}$ returned to baseline levels. This is consistent with studies showing that after status epilepticus or ischemia, intracellular $\mathrm{pH}$ returns to normal even though extracellular $\mathrm{pH}$ remains acidified.[18,20] This may occur in part due to metabolic acid consumption and to enhanced $\mathrm{H}^{+}$extrusion promoted by membrane ion pumps. It is not possible to evaluate the recovery of intracellular $\mathrm{pH}$ in our study. However, the transient decrease in extracellular $\mathrm{HCO}_{3}$ - in the postischemic period suggests that it may occur at the expense of extracellular acidosis. A slower recovery of extracellular $\mathrm{pH}$ may occur because of $\mathrm{H}^{+}$or $\mathrm{HCO}_{3^{-}}$exchange across the blood-brain barrier.

\section{Acidosis in Relation to Other Parameters}

The development of tissue acidosis has been related to other parameters such as cerebral blood flow $(\mathrm{CBF})$, adenosine triphosphate (ATP), and ion homeostasis during ischemia. Using triple-barreled ion-sensitive electrodes to measure extracellular $\mathrm{pH}, \mathrm{K}^{+}$, and $\mathrm{Ca}^{++}$, Harris and Symon[6] found that $\mathrm{pH}$ began to decrease when CBF was decreased to 30 to $35 \mathrm{ml} \cdot 100 \mathrm{~g}^{-1} \cdot \mathrm{min}^{-1}$ during bilateral carotid occlusion in rats. Marked acidotic shifts were seen when CBF decreased to $15 \mathrm{ml} \cdot 100 \mathrm{~g} \mathrm{~g}^{-1} \cdot \mathrm{min}^{-1}$ and extracellular $\mathrm{K}^{+}$simultaneously increased. A decrease in $\mathrm{pH}$ greater than $0.6 \mathrm{U}$ was associated with rapid increases in $\mathrm{K}^{+}$and decreases in extracellular $\mathrm{Ca}^{++}$. In baboons, Harris, et al.,[5] measured tissue $\mathrm{PO}_{2}$, $\mathrm{pH}$, and $\mathrm{K}^{+}$while $\mathrm{CBF}$ was decreased to ischemic levels by MCA occlusion combined with contralateral carotid constriction. The $\mathrm{PO}_{2}$ decreased rapidly when CBF fell to $30 \mathrm{ml} \cdot 100 \mathrm{~g}^{-1} \cdot \mathrm{min}^{-1}$ and $\mathrm{pH}$ fell when CBF decreased below $20 \mathrm{ml} \cdot 100 \mathrm{~g}^{-1} \cdot \mathrm{min}^{-1}$. Extracellular $\mathrm{K}^{+}$increased when CBF fell to $10 \mathrm{ml} \cdot 100$ $\mathrm{g}^{-1} \cdot \mathrm{min}^{-1}$. Modest increases in $\mathrm{K}^{+}$were seen when $\mathrm{pH}$ decreased by $0.3 \mathrm{U}$ and rapid increases in $\mathrm{K}^{+}$were seen when $\mathrm{pH}$ decreased 0.6 U. Obrenovitch, et al.,[17] measured tissue ATP, pH, and lactate during MCA occlusion in baboons. Tissue $\mathrm{pH}$ did not change until CBF decreased below $30 \mathrm{ml} \cdot 100 \mathrm{~g}^{-1} \cdot \mathrm{min}^{-1}$. Decreases in $\mathrm{pH}$ to 6.25 occurred at a CBF of $20 \mathrm{ml} \cdot 100 \mathrm{~g}^{-1} \cdot \mathrm{min}^{-1}$. Sharp boundary zones were seen between low and normal $\mathrm{pH}$, and brain tissue acidification was closely related to lactate accumulation and decreased ATP. These results indicate that when CBF is decreased to ischemic levels, tissue $\mathrm{PO}_{2}$ decreases initially, followed by decreases in ATP and $\mathrm{pH}$. When neuronal $\mathrm{pH}$ decreases more than $0.6 \mathrm{U}$, $\mathrm{K}^{+}$and $\mathrm{Ca}^{++}$homeostasis are impaired.

Although exposure of neurons to critical levels of acidosis leads to cell death, modest decreases in tissue $\mathrm{pH}$ may attenuate injury by suppressing neuronal electrical and metabolic activity.[1,21] Nakai, et al.,[14] simultaneously measured $\mathrm{CBF}, \mathrm{pH}$, and glucose metabolism using triple-tracer autoradiography during MCA occlusion in rats. They found that $\mathrm{CBF}$, glucose metabolism, and $\mathrm{pH}$ were all lower in the ischemic region of hyperglycemic rats. This may be produced in part by an increase in $\mathrm{K}^{+}$conductance 
and may be related to a decrease in the ATP/adenosine diphosphate ratio.[2] This is consistent with radiological studies showing that ischemia is associated with decreases in local neuronal metabolism.[7]

\section{CONCLUSIONS}

Studies suggest that enhanced neuronal damage is produced by ischemia when lactate approaches 18 to $20 \mu \mathrm{mol} / \mathrm{g}$.[16] Marked decreases in $\mathrm{PO}_{2}$ and $\mathrm{pH}$ occur at threshold CBF levels of 30 and $20 \mathrm{ml} \cdot 100$

$\mathrm{g}^{-1} \cdot \mathrm{min}^{-1}$, respectively, and loss of ionic homeostasis may occur at a CBF level of $10 \mathrm{ml} \cdot 100 \mathrm{~g}^{-1} \cdot \mathrm{min}^{-1}$ when $\mathrm{pH}$ has decreased to approximately 6.6. Our results suggest that ischemic changes in tissue $\mathrm{PCO}_{2}$, $\mathrm{H}^{+}$, and $\mathrm{HCO}_{3}{ }^{-}$can be measured during ischemic events in patients. The magnitude of these changes may be used to predict the risk of ischemic neuronal injury and recovery of normal acid-base status after ischemia.

\section{References}

1. Balestrino M, Somjen GG: Concentration of carbon dioxide, interstitial $\mathrm{pH}$ and synaptic transmission in hippocampal formation of the rat. J Physiol 396:247-266, 1988

2. Ekholm A, Asplund B, Siesjo BK: Perturbation of cellular energy state in complete ischemia: relationship to dissipative ion fluxes. Exp Brain Res 90:47-53, 1992

3. Gennari FJ, Cohen JJ, Kassirer JP: Determinants of plasma bicarbonate concentration and hydrogen ion balance, in Cohen JJ, Kassirer JP (eds): Acid-Base. Boston: Little, Brown, 1982, pp 55-97.

4. Goldman SA, Pulsinelli WA, Clarke WY, et al: The effects of extracellular acidosis on neurons and glis in invitro. J Cereb Blood Flow Metab 9:471-477, 1989

5. Harris RJ, Richards $\mathrm{PG}$, Symon L, et al: $\mathrm{pH}, \mathrm{K}^{+}$, and $\mathrm{PO}_{2}$ of the extracellular space during ischaemia of primate cerebral cortex. J Cereb Blood Flow Metab 7:599-604, 1987

6. Harris RJ, Symon L: Extracellular $\mathrm{pH}$, potassium, and calcium activities in progressive ischaemia of rat cortex. J Cereb Blood Flow Metab 4:178-186, 1984

7. Heiss WD, Huber M, Fink GR, et al: Progressive derangement of periinfarct viable tissue in ischemic stroke. J Cereb Blood Flow Metab 12:193-203, 1992

8. Hoffman WE, Charbel FT, Edelman G, et al: Brain tissue acid-base response to hypercapnia in neurosurgical patients. Neurol Res 17: 417-420, 1995

9. Hoffman WE, Charbel FT, Edelman G, et al: Brain tissue oxygen pressure, carbon dioxide pressure and $\mathrm{pH}$ during ischemia. Neurol Res 18:54-56, 1996

10. Katsura K, Ekholm A, Siesjo BK: Tissue $\mathrm{PCO}_{2}$ in brain ischemia related to lactate content in normoand hypercapnic rats. J Cereb Blood Flow Metab 12:270-280, 1992

11. Kazemi $\mathrm{H}$, Shannon C, Carvallo-Gil E: Brain $\mathrm{CO}_{2}$ buffering capacity in respiratory acidosis and alkalosis. J Appl Physiol 22:241-246, 1967

12. Kraig RP, Petito CK, Plum F, et al: Hydrogen ions kill brain cells at concentrations reached in 
ischemia. J Cereb Blood Flow Metab 7:379-386, 1987

13. Kraig RP, Pulsinelli WA, Plum F: Hydrogen ion buffering during complete brain ischemia. Brain Res 342:281-290, 1985

14. Nakai H, Yamamoto YL, Diksic M, et al: Triple-tracer autoradiography demonstrates effects of hyperglycemia on cerebral blood flow, $\mathrm{pH}$, and glucose utilization in cerebral ischemia or rats. Stroke 19:764-772, 1988

15. Nedergaard M, Goldman SA, Desai S, et al: Acid-induced death in neurons and glia. J Neurosci 11:2489-2497, 1991

16. Nedergaard M, Kraig RP, Tanabe J, et al: Dynamics of interstitial and intracellular $\mathrm{pH}$ in evolving brain infarct. Am J Physiol 260:R581-R588, 1990

17. Obrenovitch TP, Garofalo O, Harris RJ, et al: Brain tissue concentrations of ATP, phosphocreatine, lactate, and tissue $\mathrm{pH}$ in relation to reduced cerebral blood flow following experimental acute middle cerebral artery occlusion. J Cereb Blood Flow Metab 8:866-874, 1988

18. Siesjo BK: Acid-base homeostsis in the brain: physiology, chemistry, and neurochemical pathology. Prog Brain Res 63: 121-154, 1985

19. Siesjo BK, Ekholm A, Katsura K, et al: Acid-base changes during complete brain ischemia. Stroke 21(Suppl 11):III194-III199, 1990

20. Smith ML, Von Hanwehr R, Siesjo BK: Changes in extra- and intracellular pH in the brain during and following ischemia in hyperglycemic and in moderately hypoglycemic rats. J Cereb Blood Flow Metab 6:574-583, 1986

21. Van Nimmen D, Weyne J, Demeester G, et al: Local cerebral glucose utilization during intracerebral pH changes. J Cereb Blood Flow Metab 6:584-589, 1986

22. Von Hanwehr R, Smith ML, Siesjo BK: Extra- and intracellular $\mathrm{pH}$ during near-complete forebrain ischemia in the rat. J Neurochem 46:331-339, 1986

Manuscript received December 9, 1996.

Accepted in final form April 19, 1997.

Address reprint requests to: William E. Hoffman, Ph.D., Anesthesiology Department, University of Illinois Hospital, 1740 West Taylor, Suite 3200, Chicago, Illinois 60612. email: whoffman@uic.edu

Click here to view Commentary on this article. 